\title{
Possibilities of using natural mineral waters in the treatment of patients with non-alcoholic fatty liver disease
}

GUSHCHA Sergey ${ }^{1}$, DRAGOMIRETSKA Natalia ${ }^{1}$, ZABOLOTNA Iryna ${ }^{1}$, NASIBULLIN Boris ${ }^{1}$, IZHA Anna ${ }^{1}$, BADIUK Natalia ${ }^{2}$, KOIEVA Khrystyna ${ }^{1}$

Coresponding author: Sergey Gushcha E-mail address: gushchasergey@rambler.ru

1. State Institution «Ukrainian Scientific-Research Institute of Medical Rehabilitation and Balneology, the Ministry of Public Health of Ukraine», Odessa.

2. State Enterprise Ukrainian Research Institute for Medicine of Transport, the Ministry of Public Health of Ukraine»,

Odessa.

\section{Abstract}

Non-alcoholic fatty liver disease (NAFLD) is a chronic pathology that is increasingly diagnosed in different countries. The pathogenesis of NAFLD associated with insulin resistance, abdominal obesity, atherogenic dyslipidemia, arterial hypertension, endothelial dysfunction, impaired adipokine secretion, that is, components of metabolic syndrome. Treatment of NAFLD should be comprehensive and lengthy, although there are no standardized approaches to the treatment of NAFLD. Meanwhile, drug therapy carries certain risks: the development of serious adverse reactions with prolonged use. The work highlights modern views on the etiology, epidemiology, pathogenesis, drug and non-drug treatment of non-alcoholic fatty liver disease (NAFLD). Experimental and clinical studies on the mechanism of biological action, the effects of using different in composition and mineralization of mineral waters on the course of NAFLD had presented. Based on experimental and clinical studies, ideas about the specificity of the action of mineral waters of various balneological types and mineralization on the clinical course of NAFLD at different stages of the disease, the effect on the functional state of the liver, and the dynamics of lipid and carbohydrate metabolism had detailed. It is concluded that mineral waters could be successfully used in the complex treatment of NAFLD patients.

Key words: non-alcoholic fatty liver disease, insulin resistance, dyslipidemia, mineral waters,

\section{Introduction}

Non-alcoholic fatty liver disease (NAFLD) is a chronic pathology that is increasingly diagnosed in different countries (1). Depending on the diagnostic method, age, gender, and ethnicity of patients, the frequency of NAFLD in the adult population are from 17 to $46 \%(2,3,4,5)$. Moreover, NAFLD is found not only in patients with obesity and metabolic syndrome, where its frequency reaches $60-80 \%$ (6) but also in $7 \%$ of individuals with normal body weight, mainly in young women with normal levels of liver enzymes $(1,7)$. According to the latest meta-analysis of 86 clinical studies in 22 countries, the frequency of NAFLD in the general population is $25 \%$, reaching maximum values among the population of the Middle East and South America. It is assumed that by 2030, NAFLD will become the main cause of liver transplantation in developed countries (8). Studies in the Asia-Pacific region have identified a growing prevalence of the European diet, the popularization of fast food, a decrease in the diet of plant foods, an increase in the consumption of meat products and fats by 7 times, which, according to the authors, would leaded to an increase in the prevalence of NAFLD. It is noted that increasingly this pathology acts as a cause of mortality (9).

As part of a study conducted by American scientists [8], a model was developed to assess the progression of NAFLD, when the predicted changes in the development of liver cirrhosis associated with NAFLD, progressive liver diseases, and associated mortality had estimated until 2030. According to the results of the analysis, we can expect that the prevalence of NAFLD cases will increase by $21 \%$ from $83,300,000$ (30\% among people over 15 years old and $25.8 \%$ among all age groups) in 2015 to $100,900,000$ (33.5 and $28.4 \%$, respectively) in 2030. At the same time, the number of cases of nonalcoholic stenotic hepatitis (NASH) will increase by $63 \%$ - from 16.5 to 27 million people. The number of patients with advanced liver disease will increase by $160 \%$, from about $3,300,000$ to $7,900,000$ by 2030. The incidence of decompensated cirrhosis will increase by $168 \%$, while the incidence of 
hepatobillary carcinoma - by $137 \%$. It is noted that the growth in mortality from liver diseases in 2030 will be $178 \%$ compared to (8). The same authors came to the conclusion that in order to reduce the burden of the disease, strategies are needed to slow down the growth of cases of diseases, as well as to improve therapeutic options, because while maintaining high rates of prevalence of obesity and type II diabetes in adults, as well as taking into account the aging population, morbidity and mortality from NAFLD in the US will increase (8).

In general, at the beginning of the XXI century the concentration of "improper lifestyle" factors contributing to the development of NAFLD in the urban population (overeating and unbalanced diet, inadequate physical activity, chronic stress and arterial hypertension, environmental pollution, drug toxicity) was extremely high. This happened against the background of a simultaneous active restructuring of traditional food technologies - a process that accelerated at the beginning of the XXI century and had led to the fact that in the standard diet of the urban population of industrialized countries the content of foods containing vegetable fiber, irreplaceable polyunsaturated fats and antioxidants was sharply reduced and fast food was popularized. Indeed, for countries whose economies are only developing, the common is:

- low incomes of the population;

- the process of active urbanization has recently begun and the need for more recently the rural population to adapt to the high nervousness of life in the metropolis during the life of 1-2 generations;

- urban lithogenic and atherogenic diet;

- high levels of toxic pollution of the environment and food. All this, along with the high steatogenicity of the modern urban diet (typical for the USA, for example) leads to the rapid development of liver steatosis, as the base of NAFLD and its subsequent stages (10 -14).

Further growth of NAFLD and non-alcoholic NASH is found in all racial and ethnic groups of the countries of the world, increasing hepatic and cardiovascular morbidity and mortality. Analysis of mortality of NAFLD patients identified three main causes: cardiovascular events (13-38\%), malignant neoplasms (6-28\%) and liver pathology (2.8-19.0\%) $(1,2,14,15)$.

The traditional risk factors for developing NAFLD include: eating high-calorie foods, a sedentary lifestyle, obesity with a visceral type of fat distribution, type 2 diabetes mellitus, atherogenic dyslipidemia.

There is growing evidence that NAFLD is a multisystemic disease that increases the risk of developing not only type 2 diabetes mellitus (DM) and cardiovascular disease, but also osteoporosis, hypogonadism, hypothyroidism, polycystic ovary syndrome, kidney pathology, etc. $(36,8)$.

The pathogenesis of NAFLD associated with insulin resistance, abdominal obesity, atherogenic dyslipidemia, arterial hypertension, endothelial dysfunction, impaired adipokine secretion, that is, components of metabolic syndrome .

NAFLD is partially associated with the pathology of the biliary tract, peptic ulcer, pancreatitis, gastroesophageal reflux disease, irritable bowel syndrome $(6,7)$. Today, despite the complexity of the etiopathogenesis of NAFLD, many of its mechanisms have already been studied. But the question of the treatment of this disease is still open (14).

Treatment of NAFLD should be comprehensive and lengthy, although there are no standardized approaches to the treatment of NAFLD. First of all, therapeutic tactics provide for a modification of lifestyle and drug exposure. Lifestyle modification is aimed at correcting body weight using a hypocaloric diet and adequate physical activity $(8,9,14)$.

The success of drug therapy is associated with the appointment of insulin resistance and statins, ursodeoxycholic acid, essential phospholipids, drugs with antioxidant effects (vitamin E), etc. $(7,11,14)$. Meanwhile, drug therapy carries certain risks: the development of serious adverse reactions with prolonged use (for example, aggressive statin therapy with concomitant dyslipidemia), allergic manifestations, polypharmacy, and some of them (for example, vitamin E) can increase mortality from various causes, in particular, from hemorrhagic stroke and prostate cancer. Also, the results of drug therapy are not always satisfactory. All this reduces compliance and adherence to treatment $(4,11,14$, 15).

Summing up the cited material, we can conclude that, despite the current progress in the treatment of NAFLD patients, there are still many open questions. This stimulates the search for new nondrug treatment technologies for NAFLD aimed at developing differentiated methods of rehabilitation treatment of patients of this nosological form using natural and preformed physical factors because now 
there is no single conceptual approach to such treatment of NAFLD patients.

Recent years have proved the fundamental possibility of drinking mineral water (MW) to influence the course of metabolic processes in lipid and carbohydrate metabolism disorders in patients of different nosological groups, including those with metabolic syndrome, which is often associated with NAFLD (16])

According to modern concepts, the name "mineral water" refers to groundwater that has a therapeutic effect on the human body, due to the increased content of useful biologically active components, their ionic and gas composition, and the general ionsalt composition of water. MW are not only complex multicomponent anionic cationic solutions, but they also have a diverse composition and different mineralization, which makes it possible to vary the drinking treatment depending on the phase of the disease, the severity of the pathological process and associated pathology.

Numerous experimental and clinical studies have proven the ability of MW of various composition and mineralization to stimulate the production of intestinal and pancreatic hormones $(17,18)$. These studies allow us to consider the role of gastrin as a pacemaker, which triggers all the sequential regulatory processes of the gastrointestinal tract, and glucagon - is a hormone that enhances the level of metabolic processes. Besides, together with other hormones, they perform adaptive functions. Already a single intake of MW causes a whole cascade of hormonal reactions due to a certain sequence and relationship. The beginning of the multi-chain reaction is the entero-insular axis: enteric signals to islet cells are ahead of signals from the internal environment of the body (19).

Mineral waters act on the digestive organs and the body directly (contact, directly, quickly), mobilize homeostatic systems from molecular to a higher level of biological integration and affect the pathological process. MW act "indirectly" from the gastroenteropancreatic endocrine system, acting on the endocrine, paracrine and neuroendocrine channels of regulation.

So, the mechanism of action of drinking mineral waters is associated not only with the accumulation of ions, but with their effect on the endocrinocytes of the intestinal hormonal system, which forms urgent and long-term adaptive reactions that mediate the functioning reserves of both regulatory units and various organs and the whole organism (20).
The course intake of MW due to the general training effect causes a long-term restructuring of the pituitary-adrenal and other systems, as well as mineral metabolism, which leads to an increase and improvement of the regulatory abilities of the body (5).

Studies of the regulatory effects of MW on the activity of the gastrointestinal tract have established the presence of important phenomena: the first is an increase in the sensitivity of pancreatic beta cells to the stimulating effects of MW. The second - the maximum rise in insulin after a course of taking MW occurs not at the 15th minute, as in the initial state, but already on the 5th. The biological significance of this phenomenon can be figuratively compared with the "early warning device," since it is the usefulness of the early phase of insulin secretion that creates the conditions for the optimal course of postprandial metabolic reactions.

The third phenomenon is directly related to increasing the duration and quality of human life. Of all the hormones in this regard, most researchers note the special role of serotonin. Analysis of the obtained experimental data showed that after a course of taking MW, along with other hormones, the basal level of serotonin rises by almost $75 \%$. In this case, similarly to insulin, the early phase of serotonin secretion is stimulated. In general, an increase in the general nonspecific resistance of the organism as a result of the course of exposure to mineral water is achieved not only by activating hormones of the intestinal hormonal system, but also by adaptive restructuring of the activity of hormonal systems of higher levels of biological integration, where activation of the early phase of insulin and serotonin secretion is decisive $(17,21)$.

In experimental studies of Reps V.F., dedicated to the justification of the therapeutic and prophylactic use of drinking mineral waters for impaired liver function, it was convincingly proved that the pathogenic effects of aggressive and toxic factors have a powerful effect on energy metabolism in the liver with subsequent systemic metabolic disorders, which are the disintegration of the insulin mechanism of regulation of carbohydrate metabolism due to changes in the activity of transport membrane enzymes in hepatocytes, enhancement of lipid peroxidation (LPO) and the further development of dyslipidemia and formation of fatty liver (22).

In experimental modeling of pathological conditions, the course intake of drinking mineral 
water has a stimulating effect on insulin secretion, inhibits lipid peroxidation processes, increasing AOS power, and normalizes the activity of transport ATPases in the liver cells. The dependence of the influence of mineral waters of various salinity on the course of the pathological process depending on its severity was demonstrated (22).

A concept has been formed on the mechanism of the optimizing effect of mineral waters on hormonalenzymatic regulation of metabolism, which consists inactivating a certain sequence of reactions: in the first minutes, lipid peroxidation in hepatocyte membranes is enhanced with the simultaneous mobilization of glucose, then (up to the 30th minute) against the background of increase in peak In the early phase of insulin increment, processes of active glucose transport through the cell membrane and its utilization in the cell along the pentose phosphate pathway are enhanced. The cycle of these reactions ends with an increase in the level of free fatty acids, which indicates an increased use of lipids as energy substrates $(17,19)$.

It has been shown that an increase in the efficiency of metabolic processes during the intake of mineral waters occurs due to the activation of cortisol-insulin interaction, phase changes in the activity of the free radical oxidation system and transmembrane transfer of metabolites.

In the mechanisms of therapeutic and prophylactic action of mineral waters, one of the central places belongs to an increase in the power of antioxidant protection due to the optimization of metabolic reactions. It has been established that the insulin stimulating effect of mineral waters is directly related to their ability to inhibit lipid peroxidation $(5$, 20).

In studies conducted by N.D. Polushin and Topuria D.I. it was found that in experimental animals that received a course of mineral waters in the resort of Essentuki, the effect of various poisons on the liver is noticeably (2-3 times) (18). These primary preventive effects occur against the background of optimization of the insulin regulation of metabolic reactions and are directly related to them. The ability of the mineral waters of the Essentuki resort to optimize metabolic reactions by activating the early phase of insulin secretion during the early phase of the digestive cycle can and should be widely used to prevent the metabolic syndrome, in the pathogenesis of which the central place belongs to the disruption of the interaction of insulin with receptors on the cell membrane, which provokes the gradual development of dyslipidemia and related diseases of the cardiovascular system.

According to the data (23), the use of chloridebicarbonate sodium low-mineralized mineral water with different humic acids for 21 days in animals with experimental hepatitis was accompanied by a significant improvement in the detoxification function of the liver, an increase in basal metabolism, a decrease in inflammatory changes, normalization of liver enzymes, and an increase in protein- synthesizing function, which occurred parallel to the positive dynamics of the morphological changes of the organ.

Numerous experimental and clinical studies have proven the versatility of the therapeutic effect of MW $(5,20)$. MW can influence the regulation of the central brain structures, tissue respiration, stimulate the enteroinsular axis and release gastrointestinal hormones, enhance the function of the gastric glands, the regeneration of the gastric mucosa, normalize its motor and evacuation functions, restore the metabolism of hepatocytes, provide an immunoregulatory effect, stimulate processes bile formation, bile secretion and pancreatic secretion, harmonize relationships in the peroxidation system of lipids and antioxidant system. These general mechanisms underlie the therapeutic effects of a drinking cure.

In recent years, a small number of works have appeared that prove the effectiveness of the course drinking intake of MW in patients with NAFLD and associated diseases and conditions. At the same time, mineral waters of different composition (mineral waters of the "Esentuki", "Morshin" type, with a high content of organic substances - such as "Naftusya") provide unidirectionality, a similar effect of varying degrees of expression. Stabilization of carbohydrate metabolism through normalization of the physiological profile of insulin secretion, a decrease in insulin resistance, a decrease in dyslipidemia, a significant improvement in the basic functions of the liver and its hemodynamics were noted $(24,25)$. Studies conducted by Yu. Gerasimenko et al. Confirm the positive effect of various MW on metabolic processes in patients with type 2 diabetes mellitus (26). Low-mineralized MW with a high content of organic substances "Timan", low-mineralized sulfate-calcium-magnesium MW "Zvenigorodskaya" and medium-mineralized sulfate-bicarbonate-magnesium MW "Donat Mg" had a unidirectional effect to reduce the level of glycemia, and the higher the glycemia, the more a 
pronounced effect was exerted by MW, elimination of glucosuria and acetonuria. A similar trend was observed in lipid metabolism when there was a significant decrease in total cholesterol and triglycerides. However, in terms of lipid metabolism, "Timan" MW had a more pronounced therapeutic effect, and a more pronounced decrease in body weight occurred with the course application of "Zvenigorodskaya" MW.

A study of the effectiveness of the average mineralized sulfuric magnesium-sodium MW of the Morshin resort (source No. 6) in patients with type 2 diabetes mellitus while taking metformin and dietary support indicate a decrease in glycemia by 1.4 times (in the control - 1.2 times), possible a decrease in the level of glycosylated hemoglobin (after 3 months there was no decrease in the control), a decrease in insulin resistance $(p<0.05)$. The above changes were accompanied by normalization of ALT and AST levels ( $p<0.05)$, which did not occur in the comparison group (27).

A study of the effects of weakly carbonic, weakly mineralized hydro carbonate-magnesium-calcium MW of the Tibskoye field in the complex treatment of patients with NAFLD at the stationary stage showed an improvement in the clinical course of the disease, restoration of the functional state of the digestive system and, especially, a decrease in the levels of interleukin-6 and interleukin-8, peroxidation products lipids compared with the control. At the same time, the long-term results of this study (after 1 year) are noteworthy, when in patients who additionally took MW in the treatment complex, the number of days of temporary disability decreased by 2.5 times, the number of exacerbations decreased by 1.7 times, and the longer (8-12 months) a stable period of remission was observed in $90 \%$ of patients (28).

The use of a low-mineralized hydro carbonate calcium-sodium MW " Zapovedniy source" in combination with physical activity for 21-24 days in people with metabolic syndrome led to a significant, $42 \%$ decrease in insulin resistance according to the NOMA index, along with a possible decrease in the concentration of triglycerides and atherogenic coefficient $(\mathrm{p}<0.05)(29)$.

The study of the effect of low-mineralized sulfatebicarbonate magnesium-calcium MW "Narzan" in the complex of treatment of patients with coronary 2 . heart disease (CHD) showed a clear effect on reducing dyslipidemia, in particular, a decrease in the concentration of total cholesterol, LDL and the atherogenic coefficient $(p<0.05)(30)$.

The effectiveness of the internal course application of mineral waters of the "Essentuki" type in the treatment of NAFLD, including with simultaneous type 2 diabetes mellitus, has been convincingly demonstrated $(31,32)$. The improvement of the functional state of the liver, indicators of hepatic hemodynamics, normalization of the lipid spectrum of the blood, peroxide homeostasis, weight loss was established. The normalization of the secretion of adiponectin, leptin and a decrease in insulin resistance under the influence of these mineral waters have been proven (19). At the same time, MW "Essentuki" No. 4 (medium-mineralized carbonic acid, hydro carbonate-chloride sodium MW) had a more pronounced insulinotropic effect, and "Essentuki New" (low-mineralized carbonic acid-hydro carbonate-sulphate-sodium chloridecalcium) contributed to greater weight loss (3.5 \pm $0.4 \mathrm{~kg}$ ) taking "Essentuki New" versus $2.3 \pm$ $0.4 \mathrm{~kg}$ when taking "Essentuki No. 4").

Conclusions. Therefore, it can be argued that the mineral waters in the complex treatment of NAFLD can have a significant effect on the metabolism of lipids and carbohydrates, the restoration of the functional state of the liver. Meanwhile, the above studies are scattered and do not form a general idea of the differentiated purpose of mineral waters, depending on the stage of the underlying disease, metabolic disorders, and concomitant diseases of the digestive system. Existing data also do not answer the question about the specificity of the influence of mineral water of different composition and mineralization on the course of NAFLD.

All of the above proves the importance of studying the effect of mineral water of different chemical composition and mineralization on the course of NAFLD in the experiment and, further, in clinical studies, to prevent the progression of the underlying disease and reduce cardiometabolic risk.

\section{References}

1. Younossi ZM, Marchesini G, Pinto-Cortez H, Petta S. Epidemiology of nonalcoholic fatty liver disease and nonalcoholic steatohepatitis: implications for liver transplantation // Transplantation. 2019;103(1):22-27. doi: 10.1097/TP.0000000000002484.

2. Nseir W, Hellou E, Assy N. Role of diet and lifestyle changes in nonalcoholic fatty liver disease. World J Gastroenterol. 2014 Jul 28; 
20(28):

doi: 10.3748/wjg.v20.i28.9338.

$9338-9344$.

3. Pavlov ChS., Kuznetsova EA, Arslanyan MG, Semenistaya MCh, Glushenkov DV, Nikolenko VN. Non-alcoholic fatty liver disease: modern concepts of etiology, pathogenesis, diagnostics and treatment. Medical news of north caucasus 2017. Vol. 12. Iss. 2. P. 230 - 234. https://doi.org/10.14300/mnnc.2017.12066.

4. Lonardo A, Nascimbeni F, Maurantonio M, Marrazzo A, Rinaldi L, Adinolfi LE. Nonalcoholic fatty liver disease: Evolving paradigms. World J Gastroenterol. 2017 Sep 28; 23(36):

doi: 10.3748/wjg.v23.i36.657.1.

5. Iqbal U, Perumpail BJ., Akhtar D, Kim D, Ahmed A. The Epidemiology, Risk Profiling and Diagnostic Challenges of Nonalcoholic Fatty Liver Disease. Medicines (Basel). 2019 Mar; 6(1): 41. doi:10.3390/medicines6010041.

6. Zvenigorodskaya LA, Mkrtumyan AM, Shinkin NV, Nilova TV, Petrakov AV. Misheni metabolicheskogo tandema: nealkogolnaya zhirovaya bolezn pecheni i saharnyj diabet 2 tipa. Medicinskij sovet Targets of the metabolic tandem: non-alcoholic fatty liver disease and type 2 diabetes mellitus. Medical advice. 2017;20:20 25. https://doi.org/10.21518/2079-701X-2017-2020-25.

7. Harchenko NV, Fadeenko GD, Skripnik IN, Kurinnaya EG. Proceedings of the International Liver Disease Congress of the European Association for the Study of the Liver. Modern gastroenterology. 2014;3:107-112.

8. Younossi CD, Koening AB, Abdelatif D, Fazel Y, Henry L, Wymer M. Global epidemiology of non-alcoholic fatty liver disease - Meta-analitic assessment of prevalence incidence and outcomes. Hepatology. 2016;64 (1):73-84. doi: 10.1002/hep.28431.

9. Byrne CD, Targher G. NAFLD: a multisystem disease. J. Hepatology. 2015;62(1):47-64. doi: 10.1016/j.jhep.2014.12.012.

10. Guo Y, Xiong Y, Sheng Q, Zhao S, Wattacheril J, Flynn CR. A micro-RNA expression signature for human NAFLD progression. J. Gastroenterol. 2016;51(10):1022-1030. doi: 10.1007/s00535016-1178-0.

11. Miller ER, Pastor-Barriuso R, Dalal D, Riemersmara RA, Appel LJ, Guallar E. Metaanalysis: high-dosage vitamin E supplementation may increase all-cause mortality. Ann Intern Med
2005;142(1):37-46. doi: 10.7326/0003-4819-1421-200501040-00110.

12. Nouredding M, Mato JM, Lu SC. Nonalcoholic fatty liver disease: Update on pathogenesis, diagnosis, treatment and the role of Sadenosylmethionine // Exp. Biol.Med. 2015;240(6):809-820. doi: $10.1177 / 1535370215579161$.

13. Pastori D, Polimeni I, Baratta F, Pani A, Del Ben M, Angelico F.The efficacy and safety of statins for the treatment of nonalcoholic fatty liver disease. Dig. Liver Dis. 2015;47(1):4-11. doi: 10.1016/j.dld.2014.07.170.

14. EASL-EASD-EASO Clinical Practice Guidelines for the management of non-alcoholic fatty liver disease. J. Hepatology. 2016;64(6):1388-1402. DOI: 10.1016/j.jhep.2015.11.004.

15. Milić S, Štimac D. Nonalcoholic fatty liver disease/steatohepatitis: epidemiology, pathogenesis, clinical presentation, treatment. Dig Dis 2012;30(2):158-162. doi: $10.1159 / 000336669$.

16. Mineralni vodi Ukrayini / Za red. EO. Kolesnika, KD. Babova. Mineral waters of Ukraine / Ed. EO. Kolesnik, KD. Babov. - K.: Kupriyanov, 2005. $-576 \mathrm{c}$.

17. Efimenko NV, Mehanizmy dejstviya pitevyh mineralnyh vod $i$ ih rol $v$ kurortnoj gastroenterologii. Kurortnaya medicina. The mechanisms of action of drinking mineral waters and their role in spa gastroenterology. Spa medicine.

2015;3:2-7. http://www.gniik.ru/files/kur_medicina3 2015.pd f.

18. Zhernov VA, Frolkov VK, Zubarkina MM. [The mechanisms underlying the therapeutic effects of reflexotherapy and drinking mineral waters in the patients presenting with metabolic syndrome]. Vopr Kurortol Fizioter Lech Fiz Kult. 2017;94(2):36-41. doi: 10.17116/kurort201794236-41.

19. Botvineva LA, Nikitin EN, Melnikova LN, Akaeva EA. [Drinking mineral water and a diet with a high content of dietary fiber in the treatment of patients with type 2 diabetes]. Vopr Kurortol Fizioter Lech Fiz Kult. 2010;2:13-16.

20. Mineralni vodi Poltavshini / Za red. K.D Babova, O.M. Nikipelovoyi, O.D. Gavlovskogo. Mineral waters of Poltava region / Ed. KD Babova, OM Nikipelova, OD Gavlovsky.— Kiev: KIM, 2010: 220 p. 
21. Fizioterapiya i kurortologiya / pod red. V.M. Bogolyubova. Kniga I Physiotherapy and balneology / Ed. V.M. Bogolyubova. Book I.M.: BIONOM Publisher, 2008. — 408 c.

22. Reps V.F. Metabolicheskie mehanizmy lechebnoprofilakticheskogo dejstviya pitevyh mineralnyh vod // Ministerstvo zdravoohraneniya Rossijskoj Federacii. Pyatigorskij gosudarstvennyj nauchnoissledovatelskij institut kurortologii. Metabolic mechanisms of therapeutic and prophylactic action of drinking mineral waters // Ministry of Health of the Russian Federation. Pyatigorsk State Scientific Research Institute of Balneology Pyatigorsk: Publishing House of PGGLU, 2001: $176 \mathrm{p}$.

23. Verigo NS, Ulashik VS. Gepatotropnoe dejstvie soderzhashej guminovye kisloty hloridnogidrokarbonatnoj natrievoj mineralnoj vody (ekperimentalnoe issledovanie). Voprosy kurortologii, fizioterapii i LFK. Hepatotropic action of humic acids containing chloridehydrocarbonate sodium mineral water (experimental study). Problems of balneology, physiotherapy and physical therapy. 2015;1:3742.

24. Efimenko NV, Kaĭsinova AS, Fedorova TE, Botvineva LA. The effectiveness of the spa and health resort-based treatment with the application of Essentuki-type drinking mineral waters for the management of non-alcoholic fatty liver disease in the patients presenting with type 2 diabetes mellitus. Vopr Kurortol Fizioter Lech Fiz Kult. 2015 May-Jun; 92(3):14-17. doi: 10.17116/kurort2015314-17.

25. Shestopalov VM, Moiseeva NP, Ishenko AP, Kondratyuk EI, Usov VYu. Lechebnye mineralnye vody tipa «Naftusya» Ukrainskih Karpat i Podolya:[monografiya. Medicinal mineral waters of the type "Naftusia" of the Ukrainian Carpathians and Podolia: [monograph]. - Kyiv: Buкrek, 2013 - Київ: Букрек, 2013: 508 p.

26. Gerasimenko Yu.A., Britov AI, Chkheidze AP, Gerasimenko M.Yu. Sravnitelnaya effektivnost pitevyh mineralnyh vod $\mathrm{u}$ bolnyhsaharnym diabetom 2 tipa v sanatorno-kurortnom lechenii // Fizioterapiya, balneologiya,reabilitaciya. Comparative effectiveness of drinking mineral waters in patients with type 2 diabetes mellitus in spa treatment // Physiotherapy, balneology, rehabilitation. 2006;2:29-32.
27. Mishchuk VG, Mishchuk AV, Diba SG. Efektivnist reabilitacijnogo likuvannya hvorih na cukrovij diabet 2 tipu ta jogo vpliv na pokazniki lipidnogo spektru krovi i funkcionalnij stan pechinki // Medichna reabilitaciya, kurortologiya ta fizioterapiya. The effectiveness of rehabilitation treatment of patients with type 2 diabetes mellitus and its effect on the lipid spectrum of the blood and the functional state of the liver // Medical Rehabilitation, Balneology and Physiotherapy. 2014;1:23-27.

28. Efimenko NV, Kajsinova AS, Mercaeva ZV. i dr. Mineralnye vody $\mathrm{v}$ reabilitacii bolnyh $\mathrm{s}$ nealkogolnymi porazheniyami pecheni na stacionarnomu etape // Voprosy kurortologi, fizioterapii i lechebnojfizicheskojkultury. Mineral waters in the rehabilitation of patients with nonalcoholic liver lesions at the stationary stage // Problems of balneology, physiotherapy and physical therapy. 2012;1:17-20.

29. Frolkov VK., Mihajlyuk OV. Prirodnye i fizicheskie faktory $\mathrm{v}$ korrekcii obmela veshestv $\mathrm{u}$ pacientov $\mathrm{s}$ metbolicheskim sindromom. // Fizioterapiya, balneologiya i reabilitaciya. Natural and physical factors in the correction of substances in patients with metabolic syndrome. // Physiotherapy, balneology and rehabilitation. 2014;4:11-14. (In Russ.).

30. Leonchuk AL, Merkulova GA. Korrekciya dislipidemii $u$ bolnyh IBS pri sanatornokurortnom lechenii // Voprosy kurortologii, fizioterapii i lechebnoj fizicheskoj kultury. Correction of dyslipidemia in patients with coronary artery disease during spa treatment // Problems of balneology, physiotherapy and physical therapy. 2012;4:8-9. (In Russ.).

31. Demchenko VP, Efimenko NV, Fedorova TE, Fedorov SL, Markus MN. Effektivnost kurortnoj terapii s primeneniem pitevyh mineralnyh vod essentukskogo tipa pri lechenii metabolicheskih porazhenij pecheni u bolnyh saharnym diabetom 2-go tipa. // Fizioterapiya, balneologiya i reabilitaciya. The effectiveness of spa therapy using drinking mineral waters of the Essentuki type in the treatment of metabolic lesions of the liver in patients with type 2 diabetes. // Physiotherapy, balneology and rehabilitation. 2013;6:50-51. (In Russ.).

32. Frolkov VK. New ideas about the mechanisms of therapeutic and prophylactic action of mineral waters. Klinicheskaja medicina i farmakologija. 2015;(4):34-38. (In Russ.). 